\title{
AN ANALYSIS OF DAYLIGHTING PERFORMANCE OF LEARNING SPACES IN LOCAL GOVERNMENT SECTOR SCHOOLS IN KANDY
}

\author{
ABISHEKA WIJESUNDARA. ${ }^{*} \&$ WAJISHANI GAMAGE. ${ }^{2}$ \\ 1,2 University of Moratuwa, Sri Lanka \\ 152101A@uom.lk, 2wajishanig@uom.lk
}

\begin{abstract}
Natural lighting creates a pleasant environment, promotes healthier conditions and saves energy, and is an important factor in the design of education institutions. Many research indicates the positive impacts of better daylighting integration in educational spaces for student's health and wellbeing. For this research, an in-depth lighting integration analysis was carried out in three typical classrooms in Berrewaerts college Kandy, Sri Lanka. A field study comprised of a questionnaire-based survey and measurement of illuminance was combined with daylight simulation using Autodesk Ecotect 2011 \& Autodesk Revit. The study reveals that lack of awareness in integration of natural light with the design can either result in increasing the negative effects of excessive daylight exposure or lack of adequate daylighting. In upper levels and east facing classrooms the main problems were associated with high levels of daylight such as excessive shadow and light patches, uneven light distribution and color distribution and impede perception of objects and text. At ground floor level and south facing classrooms, when natural light is not properly integrated with the design resulted in uneven light distribution, non-uniformity of light resulted in difficulty in reading at work plane and impede the visual perception of objects and text.
\end{abstract}

Keywords: Daylighting, Architecture, Educational spaces

\section{Impact of daylighting on human wellbeing}

Oxford dictionary describes daylighting as "the illumination of buildings by natural light." Daylight is known to have both visual and non-visual effects on building occupants. Danzig, Lazarev, and Sokolov cited by Edwards and Torcellini (Edwards and Torcellini, 2002) contended that lack of exposure to daylighting for prolonged periods of time will result in vitamin D deficiency followed by weakened body defences and an aggravation of chronic diseases. UV light which results in higher levels of beta-endorphin molecule in the blood have been identified to activate feel-good processes resulting in pain relief, feeling of wellbeing and relaxation (Taylor et al., 2009, Juzeniene and Moan, 2012). Many studies have also indicated that activated vitamin D can inhibit cancer cell growth (Garland et al., 2007, Gorham et al., 2005). A study conducted by Julia (Knight et al., 2007) showed that girls between the ages on 10-19 and women aged 2029 years with higher sun exposure had $69 \%$ and 51\% lower risk of breast cancer. Hossein-Nezhad, Spira and Holick (Hossein-Nezhad et al., 2013) demonstrated that around 2000 genes are regulated by active vitamin D in our body and up to 80 different metabolic processors such as DNA repair, apoptosis, oxidative stress, metabolic processes and anti-inflammatory activity are associated with this process. Studies have shown that light has a direct effect on human health because of the way it influences the circadian rhythms. A variety of daily rhythms such as sleep, mood, body temperature, pubescence, ovulation is negatively impacted due to lack of daylight exposure (Neer, 1975, Salares and Russell, 1996, Wurtman, 1975).

Many studies demonstrate the link between daylighting and physiological health of building

*Corresponding author: Tel: +94 716858567 Email Address: 152101A@uom.lk 
occupants. In a study conducted by Wilson (Wilson, 1972) on 100 patients in an intensive care unit, he identified that as many as three times the number of cases of organic delirium occurred in patients in a ward without a window as occurred in one provided with natural light. The Ergonomic Institute in Berlin investigated more than 2000 working population for lighting-associated health defects. More than $50 \%$ of health problems in offices were found to be caused by poor lighting conditions (Cakir and Cakir, 1991). The study demonstrated how the impact of better daylighting in buildings enhances mental performance, decreases violent behaviour, decreases depression, and improves sleep. Depression and stress in the work environment have been directly linked to inadequate daylighting (Heerwagen et al., 1995). Cooper and Payne (Cooper and Payne, 1989) identified that absence of windows contributes to the stress on occupants.

\section{Effect of daylighting on Learning Environments}

In the past daylighting has been identified as a crucial factor in the design of learning environments (Manning, 1967). Although understanding of the impact of daylighting in learning environments is not conclusive, many positive benefits of daylighting have been linked to student's health and wellbeing. The positive effects of daylighting for student's health can be directly related to the previously discussed positive impacts of daylighting on general human health such as improved vitamin D levels and proper regulation of circadian rhythm. In addition, psychological impacts of daylighting on students have been linked to improved feeling of pleasantness, security, mood, sleep and reduced stress, depression and violent behaviour (Mirrahimi et al., 2013). In 1992 a study conducted on association of health, behaviour and hormone levels of 8-year-old students in four class rooms over one-year period identified a significant correlation between pattern of daylighting level, hormone levels and student behaviour. High levels of morning cortisol were identified in students who had no access to daylighting which influenced the children's ability to concentrate or co-operate, and also eventually impacted annual body growth and sick leave.' (Küller \& Lindsten, 1992). In 1999 one of the largest studies ever done on daylighting in schools conducted by Heschong Mahone Group (Heschong, Wright, \& Okura, 2002) analysed test score results for over 21000 elementary students from three districts in the USA and the impact of daylighting levels in class rooms. Their results revealed that children learned faster and did better on American standardized tests in the classrooms with good daylighting. Further studies have linked better daylighting conditions in learning environments to increased feeling of security (Boyce, Hunter, \& Howlett, 2003; Djamila, Ming, \& Kumaresan, 2011). The CIBS Lighting Code recommend minimum illuminance on the working plane to be 300 lux (Research, 1972, Yarham, 1994). Lack of adequate illuminance may result in poor visual acuity. Narasimhan and others cited by The Asian Regional Institute for School Building Research (Research, 1972) in a study conducted on 2,200 school children in Uttar Pradesh, India identified considerable association of sub normal vision in students aged 5 to 13 which was linked to prolonged use of the eye under poor lighting conditions or use with strain. They recommended higher levels of illumination in primary classes than in the secondary classes and values not less than 106 lux.

\section{Gaps in integration of daylighting in learning spaces}

The guideline for design of classrooms given by the ministry of education specifies the size of a class room for maximum number of 35 students as $20^{\prime} \times 20^{\prime}$. For new class room constructions, the size has been increased: Primary level - 25'x 25' (without corridor) and Secondary level - 20'x25' (without corridor). A typical class room block would be $90^{\prime} \times 25^{\prime}$ with a $5^{\prime}-0^{\prime \prime}$ access corridor and a recommended maximum number of three floors. There is no specified standard for visual, thermal or acoustic comfort requirement. Fenestration for a typical class room would have windows on either side or 4'-0" half wall and aluminum mesh up to the soffit.

The main problem of access to adequate daylighting for learning environments in the tropical region is threefold: extreme fluctuations, discomfort due to overheating excessive contrast and glare, and the lack of specific design guidelines. (Maitreya, 1979), identified daylighting level in tropical classroom in the hot humid climates to be generally inadequate. This may result from inefficiency of daylighting systems and complications to maximize the transfer of natural light at the same time avoiding excessive heat gain (David et al., 2011). Almost all learning spaces in government sector schools in Sri Lanka are free running and do not have climate control systems. Building facade is one of the significant architectural design elements influencing energy consumption and human comfort. Lack of adequate research and design guidelines on facade design for optimized daylighting in the tropical climates and lack of guidelines at 
master planning level for national schools in Sri Lanka, frequently result in class room blocks being located close to each other, further hindering the access to daylighting. These can be identified as some major drawback influencing optimum daylighting design in learning spaces in the majority of public school in the country. This study investigates daylighting performance of learning spaces in local government sector schools which are designed according to typical class room design requirements established by the ministry of education. The study further identifies planning related design considerations which impact the optimum daylighting performance of learning environments.

\section{Methodology}

A field survey was conducted at Berrewaerts college kandy. The school belongs to the Kandy educational division and is located facing the Kandy - Ampitiya Road. It is categorized as a $1 \mathrm{AB}$ type provincial school that consists classes up to grade 13. the survey took place within three class rooms. All participants were school students ages between 15-16 years. The layout plan, orientation of each class room is shown in Figure 1. Class room A was located on the third floor of Siyawas hall a three-story class room block, and Class room B located on 2nd floor of the same building. Class room C was located on ground floor of Berrewaerts hall which is a two-story class room block. Both buildings are leaner box shape and the class rooms are directly connected to a common corridor.
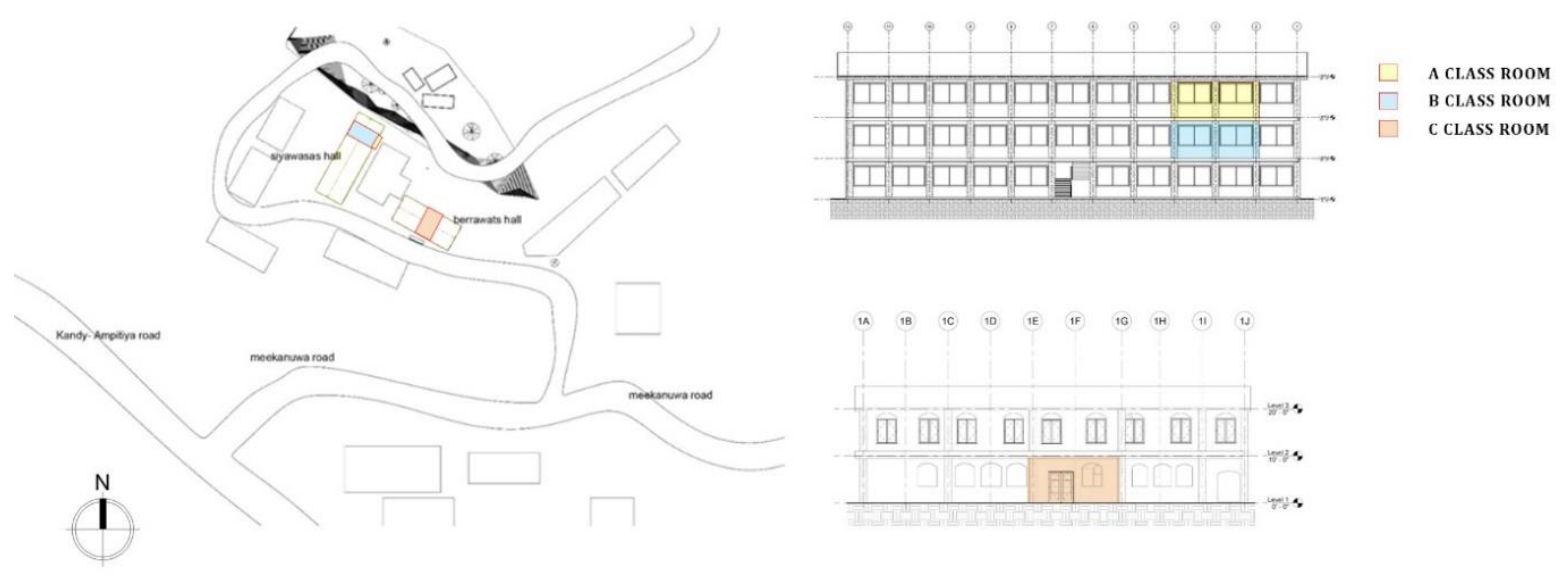

Figure 1, layout plan, orientation and façade characteristic of selected classrooms

The survey was conducted on 23 of December 2020 from $8.00 \mathrm{am}$ to $2.00 \mathrm{pm}$. The illuminance (I) was measured inside the Class rooms using HOBO data loggers MX2202 (Onset, Bourne, MA, USA) every 1 hour. All measurements were taken at $0.75 \mathrm{~m}$ height above floor. The same locations were measured in the same time using the simulation model. Autodesk Ecotect 2011 \& Autodesk Revit was used to model the classrooms. The points of field measurements and the simulation of illuminance are shown in Figure 2. The calibrated simulation for three classrooms was used for analysis of daylighting conditions within the class room for 23rd of December 2020. The BIM simulation and Ecotect model provided a more accurate representation of the natural light distribution for the defined intensity of illuminance, but unspecified. Models confirms that they allow to significantly increase the quality of the design of lighting systems through a better adaptation to the actual conditions. the accuracy of the digital models was checked by using the results of the measurements as well as to improve the lighting conditions in the classroom in order to obtain an architectural solution for the lighting design.

Students' perception of the lighting condition in the classrooms was monitored using a questionnaire survey. The questionnaire was adapted from the survey on Perceptive Spatial Analysis of Colour and Light (PERCIFAL). This is a method of visual evaluation of space and light, developed by Professor Anders Liljefors at the former department of architectural lighting at KTH Architecture (Arnkil et al., 2011). The PERCIFAL method is based on direct visual observations and the recording of these observations by verbal-semantic descriptions using a questionnaire. The variables measured through the questionnaires is summarized in Table 1. 

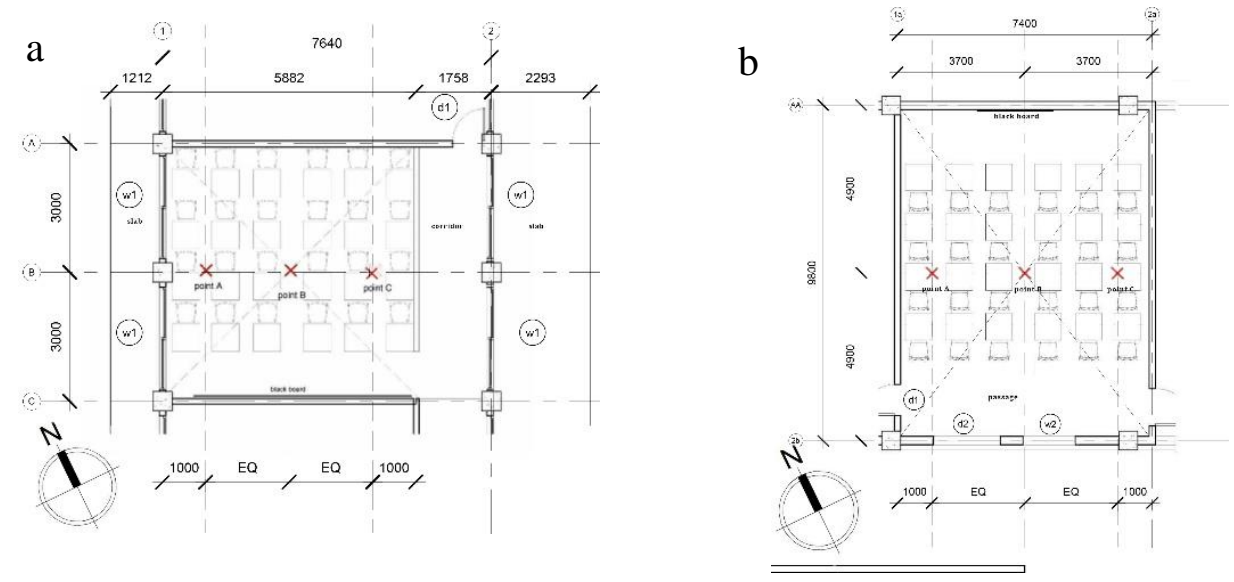

Figure 2, points of measurements and orientation of classrooms (a) Classroom A \& B (b) Classroom C

\begin{tabular}{|l|l|l|}
\hline \multirow{2}{*}{ Question } & \multicolumn{2}{|c|}{ Scale Point } \\
\cline { 2 - 3 } & 1 & 7 \\
\hline light level & Dark & Light \\
\hline light distribution & Even & Varied \\
\hline shadow & Strong Contrast & No contrast \\
\hline light patches & Strong Contrast \\
\hline Glare & Very much & Not at all \\
\hline surface colour & Warm & Cool \\
\hline surface colour: distribution & Coherent & Varied \\
\hline Perception on objects & Enhanced & Impede \\
\hline Perception on text & Facilitate & Obstruct \\
\hline
\end{tabular}

Table 1: variables measured in the questionnaire
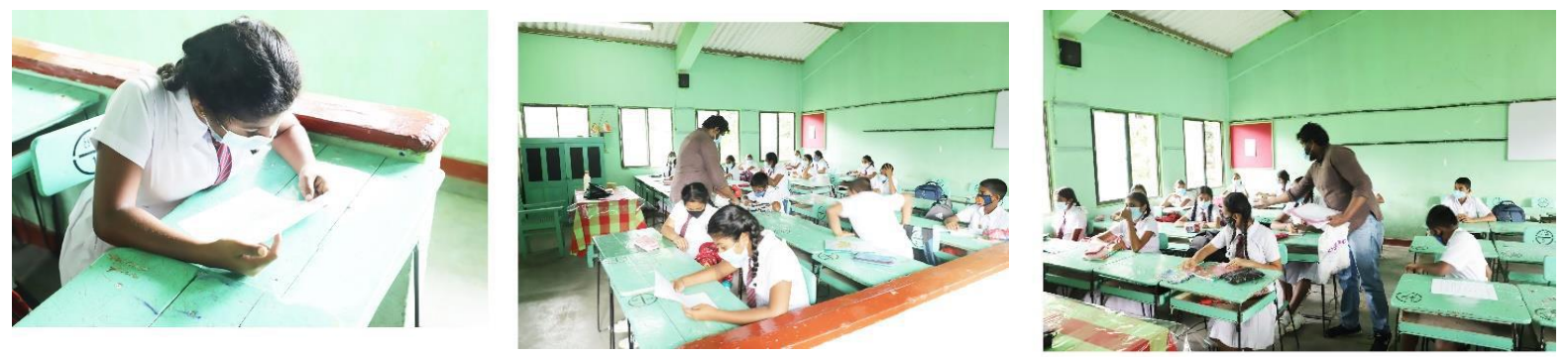

Figure 3, questionnaire survey being conducted in the classroom

\section{Results}

\subsection{DAYLIGHT SIMULATION AND FIELD MEASUREMENT CLASS ROOM A AND B}

Class room A and B is located on second and third floor of the Siyawas hall. During the summer solstice, there was high present of solar irradiance over the building. According to Revit solar analysis, the maximum amount of energy was $1173 \mathrm{Wh} / \mathrm{m}^{2}$. Figure 4 shows the specific insolation in east and west window areas, where the maximum energy received was around $1763 \mathrm{Wh} / \mathrm{m}^{2}$. Both classrooms received high amount of solar radiation on the east façade during occupied hours from $8.00 \mathrm{am}$ to $2.00 \mathrm{pm}$, the west side did not receive much direct sunlight during occupied hours. The $1.75 \mathrm{~m}$ width corridor located on the east side of the building acted as a buffer to the occupied area and reduced the impact of direct solar radiation during the morning critical hours.

The second point of solar analysis was made using the lighting tool with the aim to confirm the possibility of having spaces with sun overexposure because of its window area. Figure 5 shows results for daylight factor for classrooms A and B. The daylight factor varies in classroom A between 7-11\% and 
Classroom B range between 4-6\%, both classrooms can be considered well-lit and does not require artificial lighting during occupied hours however these spaces are vulnerable to the negative impact of visual discomfort due to glare.
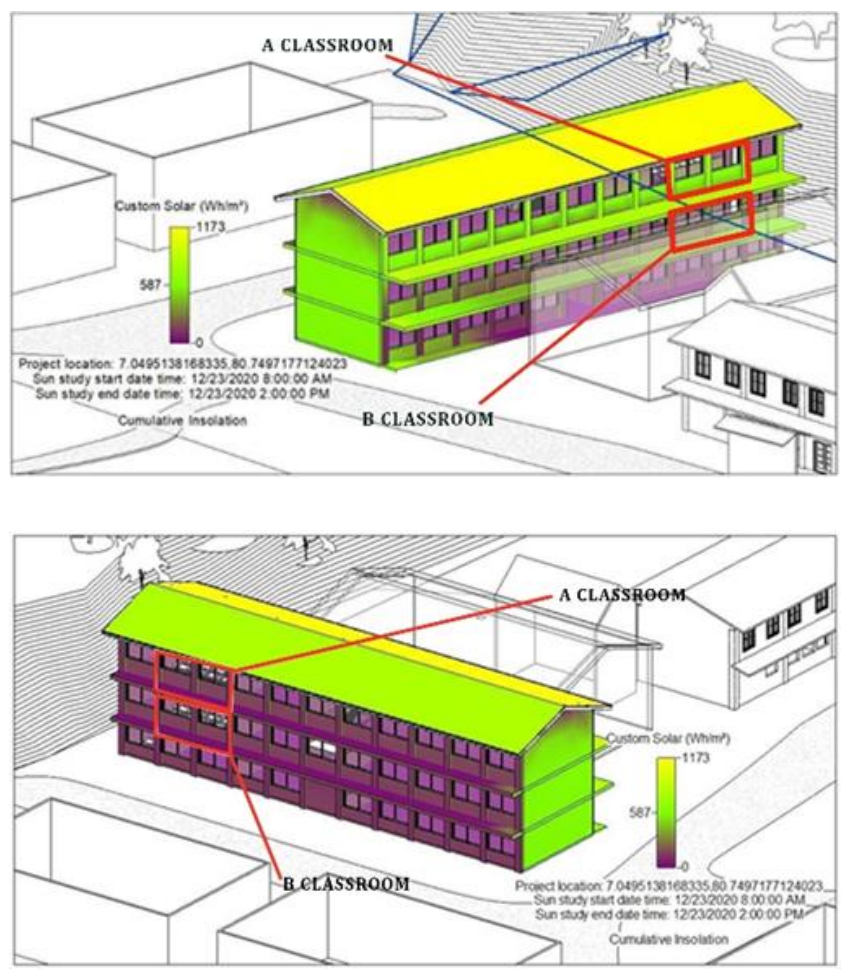

Figure 4, Cumulative insolation in A classroom and B (BIM revit2020)

Figure 6 summarize the result for illuminance measurement and simulated illuminance for in classroom A and B. High level of illuminance on the working plane on east and mid of building, the illuminance at the same points in classroom B which was located one floor below had much lower illuminance levels on the working plane and better light distribution.
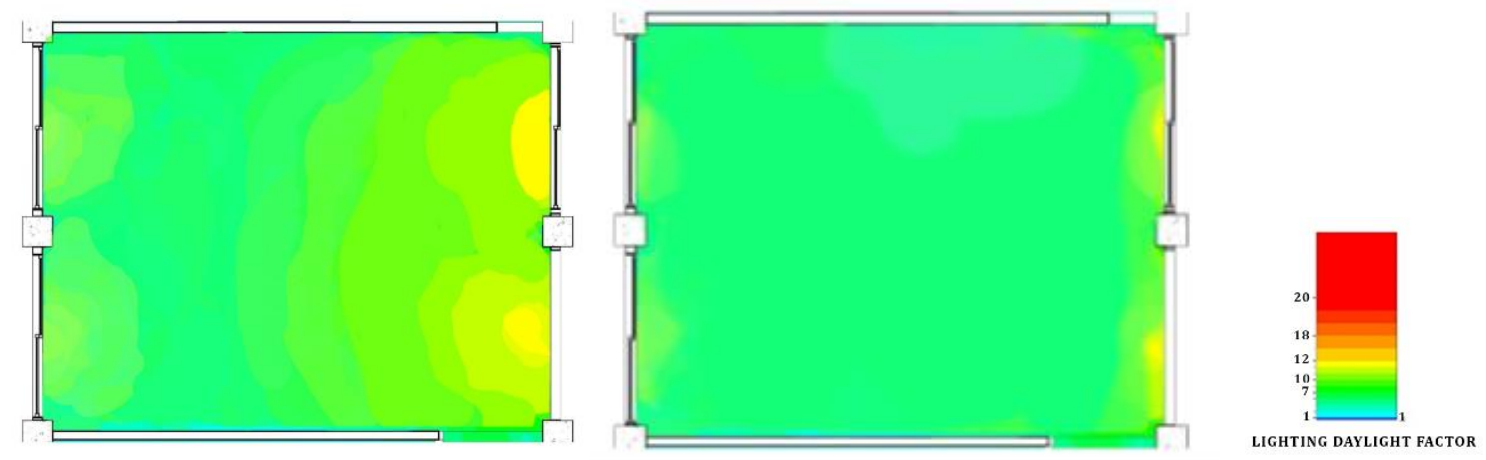

Figure 5, Lighting analysis classroom A and B BIM (Revit 2020)

\subsection{DAYLIGHT SIMULATION AND FIELD MEASUREMENT CLASS ROOM C}

Class room C is located on ground floor of Berrewaerts hall, The class room receives daylighting only from the west direction. Figure 7a shows the specific insolation in the south-west window areas, where the maximum energy received was around $1153 \mathrm{Wh} / \mathrm{m}^{2}$. Figure $7 \mathrm{~b}$ shows results for daylight factor for classroom C. The daylight factor varies in Classroom C range between 1-2\%, therefore this classroom doesn't receive adequate daylighting and need artificial lighting. Low level of daylighting is present in the east end which does not have access to daylight. Figure 8 summarize the result for illuminance 
measurement and simulated illuminance for in classroom C. There is low level of illuminance on the working plane on all measured points below 200lux.

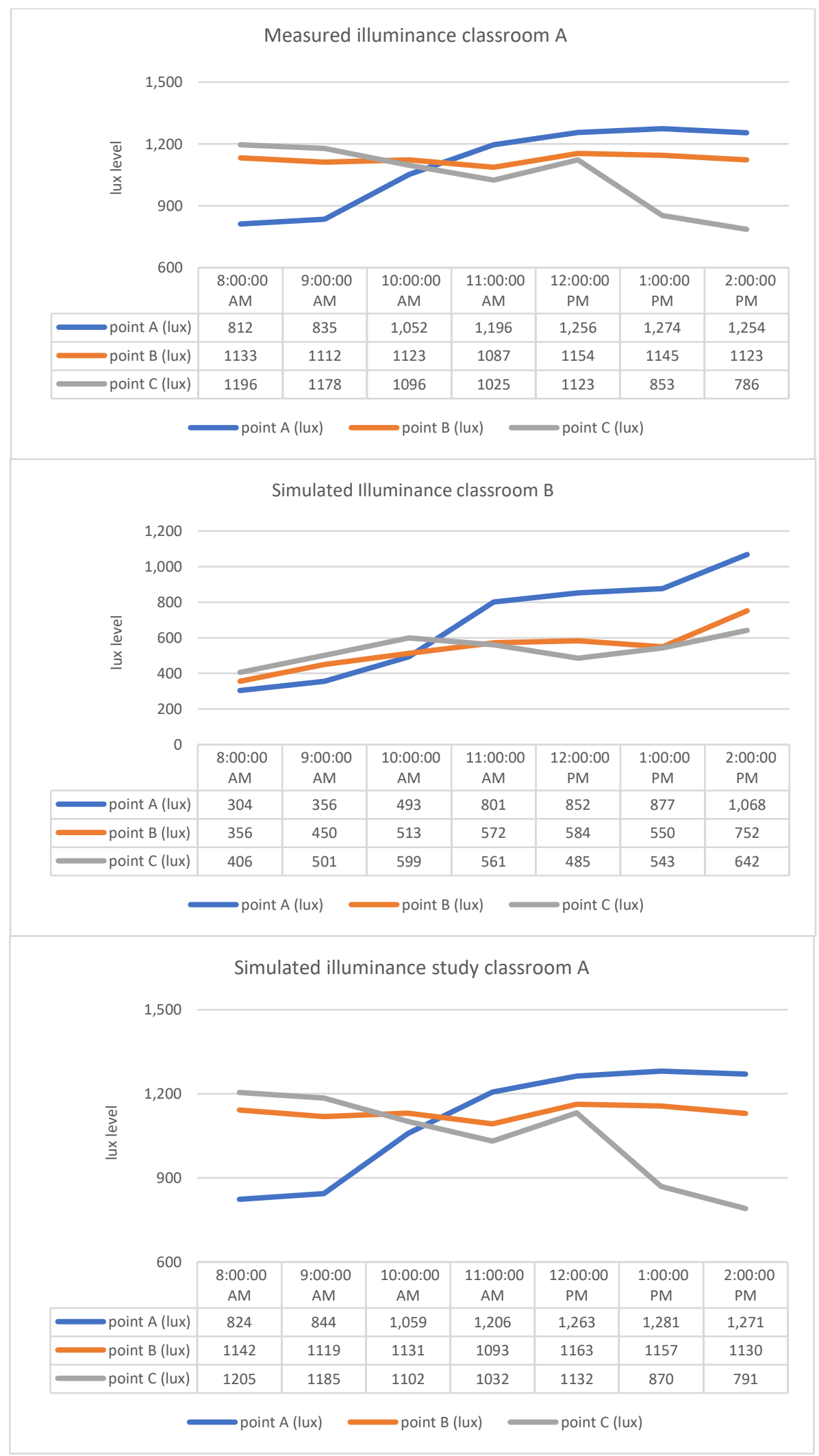




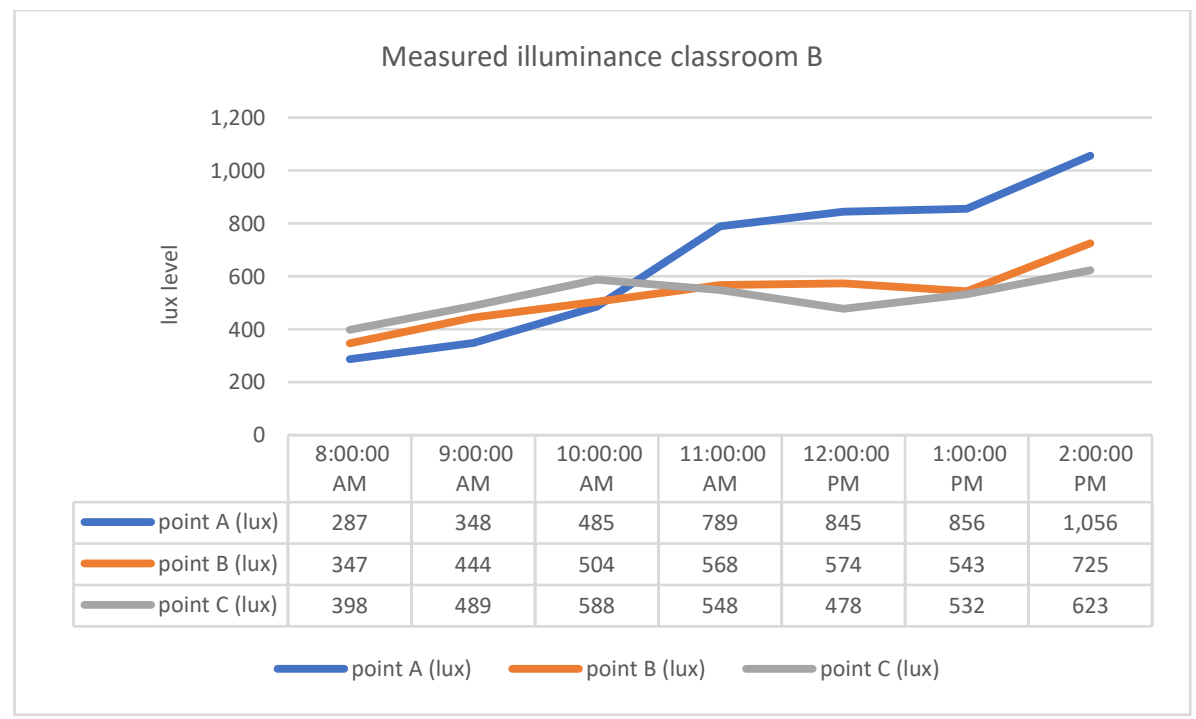

Figure 6, Measured and simulated illuminance on the working plane Class room A and B

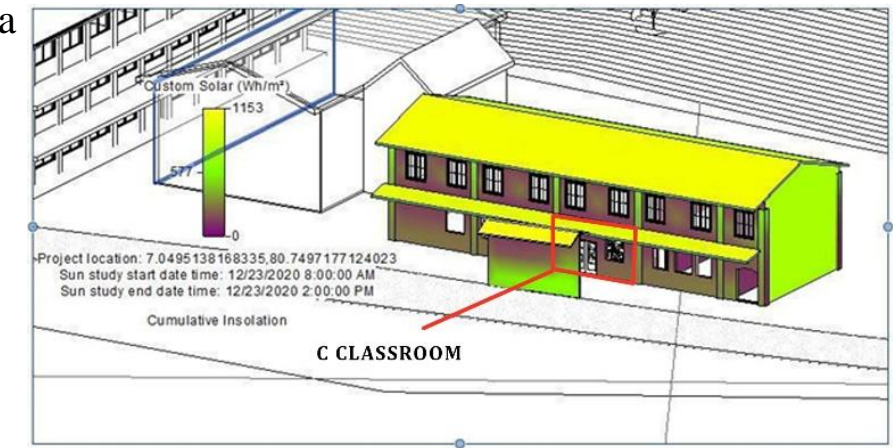

$\mathrm{b}$
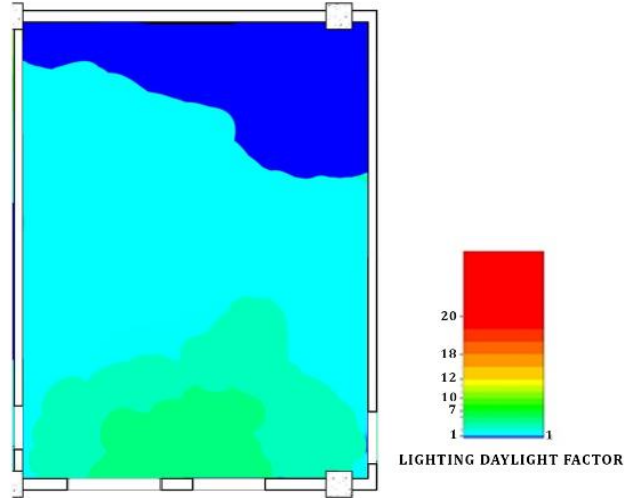

Figure 7, Cumulative insolation (a) and Lighting analysis (b) classroom B

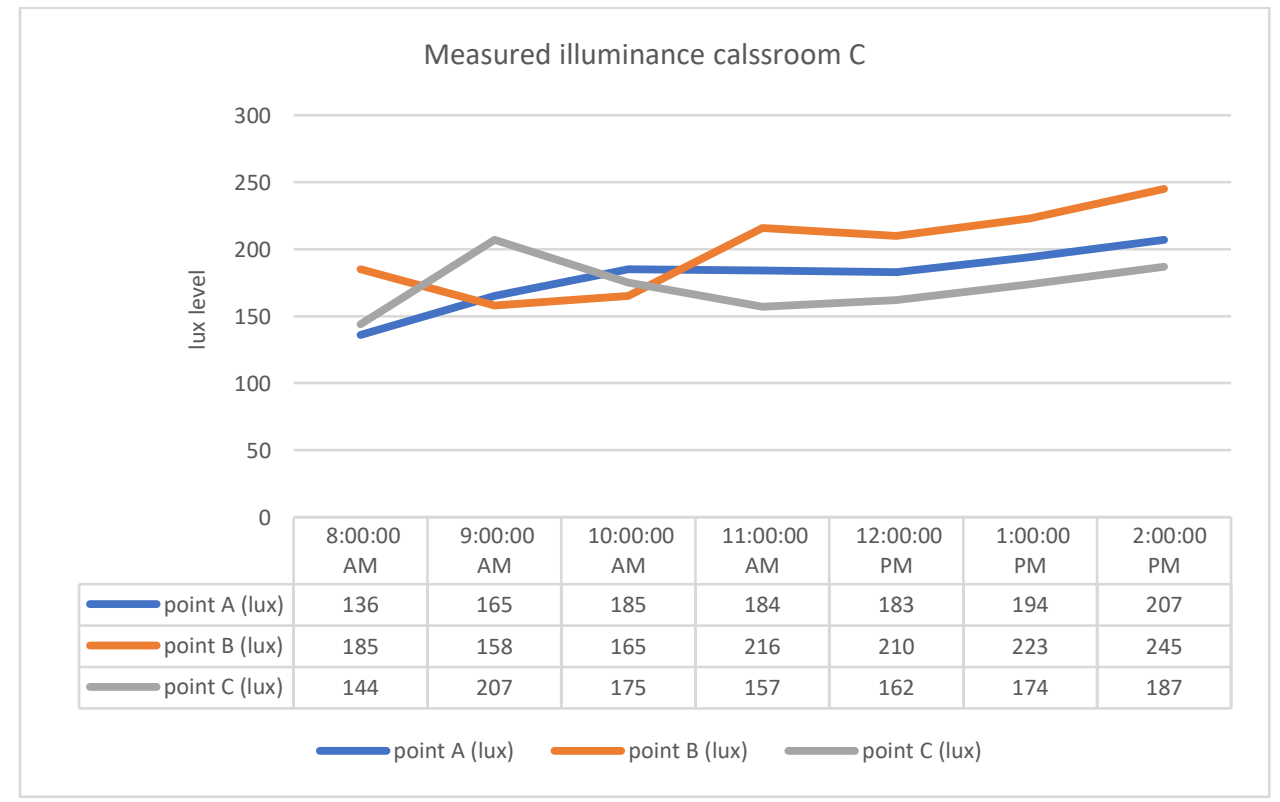




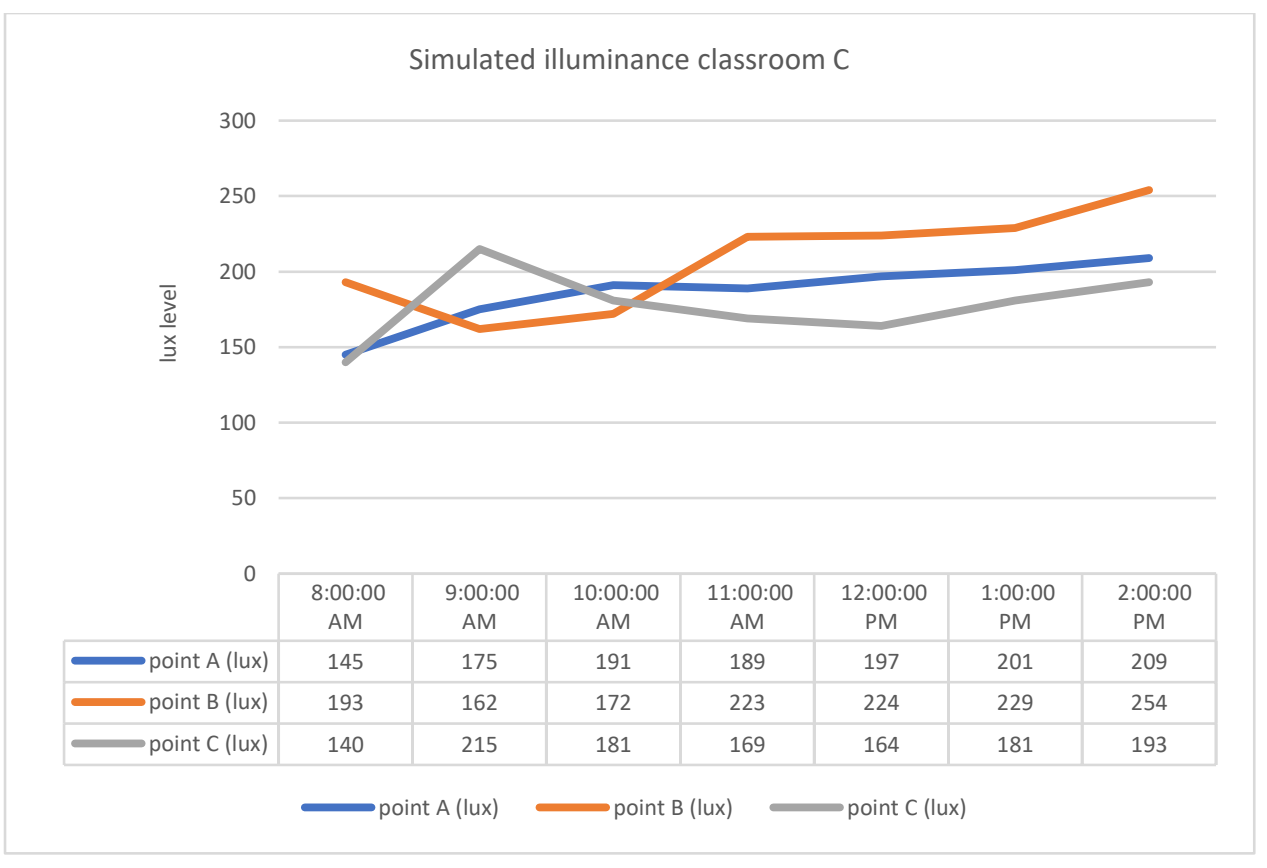

Figure 8, Measured and simulated illuminance on the working plane Class room C

\subsection{ANALYSIS OF VISUAL COMFORT PERCEPTION ON DAYLIGHT}

Visual Comfort Perception is based on several parameters such as illuminance, glare, luminance ratio, reflectance, brightness, colour rendering, colour of light, daylight factor, light distribution, direction of light and shadow. The mean scores for the student's perception of 9 variables related to daylighting were compared using one-way ANOVA and followed up with post hoc testing to determine how the students evaluated indoor daylighting condition. The results are summarized in Table 2-4.

\begin{tabular}{|l|l|l|l|l|l|}
\hline & $\mathrm{N}$ & Minimum & Maximum & Mean & Std. Deviation \\
\hline light level & 15 & 4 & 7 & 6.00 & .926 \\
\hline light distribution & 15 & 2 & 6 & 3.73 & 1.280 \\
\hline shadow & 15 & 3 & 6 & 4.53 & 1.060 \\
\hline light patches & 15 & 2 & 6 & 4.47 & 1.246 \\
\hline Glare & 15 & 1 & 5 & 3.40 & 1.183 \\
\hline surface colour & 15 & 3 & 6 & 4.27 & .961 \\
\hline surface colour: distribution & 15 & 3 & 5 & 4.00 & .756 \\
\hline Perception on objects & 15 & 1 & 5 & 3.33 & 1.234 \\
\hline Perception on text & 15 & 1 & 5 & 2.93 & 1.335 \\
\hline Valid N (listwise) & 15 & & & & \\
\hline
\end{tabular}

Table 2: Descriptive Statistics For Classroom A

\begin{tabular}{|l|l|l|l|l|l|}
\hline & $\mathrm{N}$ & Minimum & Maximum & Mean & Std. Deviation \\
\hline light level & 15 & 3 & 7 & 4.60 & .986 \\
\hline light distribution & 15 & 2 & 6 & 3.33 & 1.291 \\
\hline shadow & 15 & 3 & 6 & 4.87 & 1.060 \\
\hline light patches & 15 & 3 & 6 & 4.87 & .990 \\
\hline Glare & 15 & 3 & 7 & 4.73 & 1.100 \\
\hline surface colour & 15 & 4 & 7 & 5.13 & .990 \\
\hline surface colour: distribution & 15 & 3 & 5 & 3.80 & .676 \\
\hline Perception on objects & 15 & 1 & 5 & 2.73 & 1.163 \\
\hline Perception on text & 15 & 1 & 3 & 1.60 & .828 \\
\hline Valid N (listwise) & 15 & & & & \\
\hline
\end{tabular}

Table 3: Descriptive Statistics For Classroom B 


\begin{tabular}{|l|l|l|l|l|l|}
\hline & $\mathrm{N}$ & Minimum & Maximum & Mean & Std. Deviation \\
\hline light level & 15 & 1 & 5 & 2.80 & 1.014 \\
\hline light distribution & 15 & 2 & 7 & 4.80 & 1.424 \\
\hline shadow & 15 & 3 & 7 & 5.47 & 1.125 \\
\hline light patches & 15 & 2 & 7 & 4.87 & 1.727 \\
\hline Glare & 15 & 3 & 7 & 5.60 & 1.183 \\
\hline surface colour & 15 & 2 & 5 & 3.40 & .828 \\
\hline surface colour: distribution & 15 & 2 & 6 & 3.80 & 1.082 \\
\hline Perception on objects & 15 & 2 & 6 & 4.20 & 1.014 \\
\hline Perception on text & 15 & 1 & 5 & 3.47 & 1.506 \\
\hline Valid N (listwise) & 15 & & & & \\
\hline
\end{tabular}

Table 4: Descriptive Statistics For Classroom C

\subsubsection{Light level}

The mean illuminance level of classroom B was not perceived as too bright. But classroom A illuminance level was perceived too bright. Students reported insufficient light level on the work plane in classroom $\mathrm{C}$. Classroom A is affected by direct sunlight while the other two spaces are lit up using reflected and diffuse light. Therefore, classroom A was perceived brighter. Classroom C is lit up from the south, and has windows only on one side and was located on the ground floor, as a result subjects reported darker light level in this space. Class room B was perceived as brighter than $C$ and darker than A. Due to the shading device on ground level more daylight was reflected into classroom B, allowing for the dark corner to lighten (Figure 8).

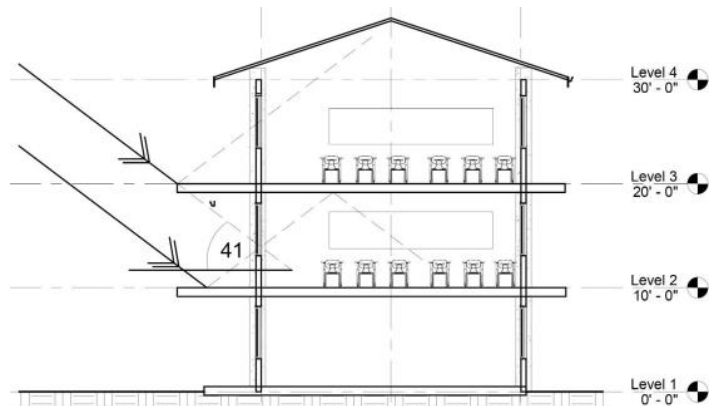

Figure 9, Daylight reflection into classroom B

\subsubsection{Light Distribution}

Uniform distribution of light is an important parameter in visual comfort. The mean value for light distribution is lowest in Class room B, indicating more even horizontal light distribution among the three spaces. In classroom $\mathrm{C}$ non-uniformity of light resulted in difficulty in reading at work plane, lack of adequate daylighting resulted in poor light distribution. Classroom $\mathrm{A}$ is lit up by direct sunlight through windows on the side walls, direct sunlight varies with the time of the day. This affects the horizontal light distribution.

\subsubsection{Shadow and light patches}

Shadows occur due to direct directional light sources. The size and shape of the shadows are determined by the position of the light source. The mean value for contrast of shadow was highest in Classroom $\mathrm{C}$, indicating less contrast than Classroom A and B. In classroom A shadows occurs due to wall above the work plane which is below the windows, which resulted in difficulty in reading. Classroom B and C use diffuse reflected light, which produce light without a pure direction. As a result of that very low contrast shadows were experienced by the students in those spaces. Classroom A tends to have more contrast as the side wall windows produce directional sunlight which can produce some shadows, especially on the working top close to the wall. Having strong shadows would bother the reading as they tend to make the space more dynamic and visually active. 


\subsubsection{Glare}

The mean value for perception of glare was highest in classroom $C$ and lowest in classroom A indicating high level of glare in classroom A, which was due to high level of direct sunlight. Class room B reported low levels of glare than classroom A.

\subsubsection{The Colour of Light and Surface colour distribution}

Surface colour in classroom $\mathrm{C}$ was perceived as the warmest from the three spaces. The chairs and tables in the classroom were painted in bright yellow colour. Classroom A used a yellowish green colour. Mixed results for perception of light colour in this space resulted due to the variability of daylight in the space, some areas were perceived as warmer than others. The students also pointed out that the green light have a negative effect for daylight perception. Cool colour was found to be more agreeable, relaxing, pleasing and natural as in classroom B. Due to better light distribution colour distribution was also found to be more coherent in classroom B.
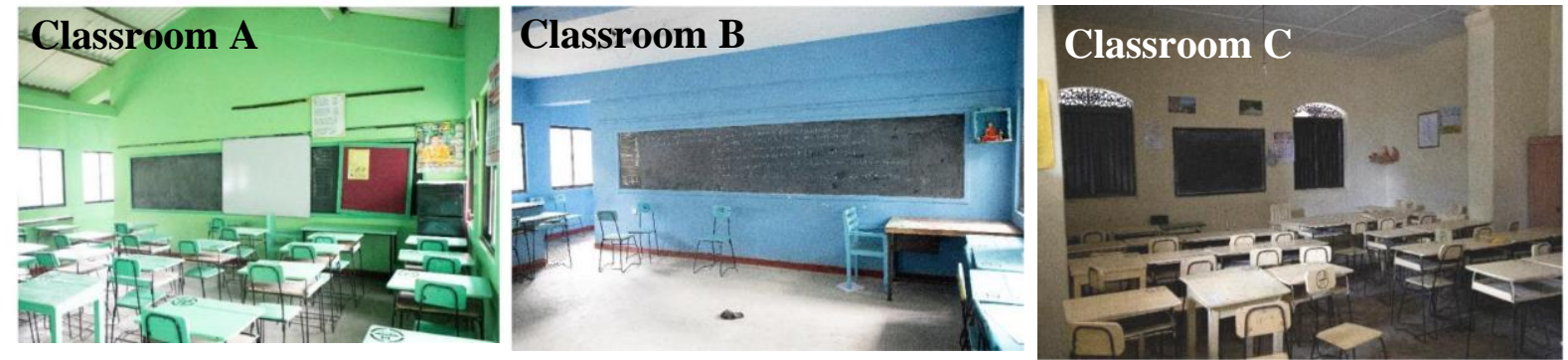

Figure 10, interior colours of the classrooms

\subsubsection{Perception of objects and text}

The low light levels in classroom $\mathrm{C}$ resulted in impede visual perception of objects. Due to diffuse reflected light shadows are at a minimum level and without certain level of shadows, it is hard to perceive visual detail of an object. In classroom B visual perception of objects was perceived as enhanced by the presence of daylighting. This may result from wall surface colour which act as a background for the colours of other surfaces and sufficient lighting level with diffuse reflected light. For visual perception of text, both classrooms A and B had more favourable conditions than classroom C. Visual perception of text was considered slightly more obstruct in classroom A than B because of the direct sunlight, shadows and directional light. Classroom B reported the best in visual perception of text as its lighting conditions enhance the activity in the space.

\section{Conclusion}

Natural lighting is an important factor in the design of education buildings as it increases productivity, promotes a healthy and pleasant environment while it reduces energy consumption that results from the use of artificial lighting. This research examined suitable architectural manipulations used to get daylight in while maintaining visual comfort perception. Considering the significant number of benefits attached to daylighting for young children, integration of natural light with the design is an important factor with respect to educational buildings. However, majority of learning spaces in local government schools has not given adequate consideration to design of good daylighting for interior. As seen in this research there is a lack of awareness on integration of natural light with the design which can either result in increasing the negative effects of excessive daylight exposure or lack of adequate daylighting. In upper levels of east facing classrooms, lack of proper shading can lead to glare, high variability in light levels, excessive shadow and light patches, uneven light distribution and color distribution and impede perception of objects and text. At the ground floor level, the main problem is related to lack of adequate daylighting, daylight opening on one side resulted in further reduction of availability of daylighting as in Classroom C. When natural light is not properly integrated with the design resulted in uneven light distribution. Non-uniformity of light resulted in difficulty in reading at work plane and impede the visual perception of objects and text. This study shows the need to address design intervention for better daylighting in relation to the 
differentiations in the orientation of the class rooms, the intensity and the spreading of daylight, rather than applying a one size fits all approach as seen in design of majority of educational spaces in Sri Lanka. Design of shading devises is a central point in west-and-east oriented class rooms to avoid direct light as well and increase the light distribution in the space. Moreover, the research looks ahead to define a set of design guidelines in the aim of optimizing the use of natural lighting and visual comfort in school buildings.

- Propose improvements depending on the different orientations of the classroom in order to deal with glare problems, maintain acceptable lighting levels as well as to reduce the use of artificial lighting.

- The need of introducing fixed louvers to the class rooms which are oriented in east-west direction

- Further improvement can be achieved by using movable and semi-transparent internal blinds

\section{References}

ARNKIL, H., FRIDELL ANTER, K., KLAREN, U. \& MATUSIAK, B. PERCIFAL: Visual analysis of space, light and colour. AIC 2011, Interaction of Colour \& Light in the Arts and Sciences, Midterm Meeting of the International Colour Association, Zurich, Switzerland, 7-10 June 2011, 2011. pro/colore, 2011, 229-232.

CAKIR, A. \& CAKIR, G. 1991. Light and Health: Influences of Lighting on Health and Well-being of Office and Computer Workers. Ergonomic Institute for Social and Occupational Sciences Research Co., Ltd., Berlin.

COOPER, C. L. \& PAYNE, R. 1989. Causes, coping and consequences of stress at work.

DAVID, M., DONN, M., GARDE, F. \& LENOIR, A. 2011. Assessment of the thermal and visual efficiency of solar shades. Building and Environment, 46, 1489-1496.

EDWARDS, L. \& TORCELLINI, P. 2002. Literature review of the effects of natural light on building occupants. National Renewable Energy Lab., Golden, CO.(US).

GARLAND, C. F., GORHAM, E. D., MOHR, S. B., GRANT, W. B., GIOVANNUCCI, E. L., LIPKIN, M., NEWMARK, H., HOLICK, M. F. \& GARLAND, F. C. 2007. Vitamin D and prevention of breast cancer: pooled analysis. The Journal of steroid biochemistry and molecular biology, 103, 708-711.

GORHAM, E. D., GARLAND, C. F., GARLAND, F. C., GRANT, W. B., MOHR, S. B., LIPKIN, M., NEWMARK, H. L., GIOVANNUCCI, E., WEI, M. \& HOLICK, M. F. 2005. Vitamin D and prevention of colorectal cancer. The Journal of steroid biochemistry and molecular biology, 97, 179-194.

HEERWAGEN, J. H., HEUBACH, J. G., MONTGOMERY, J. \& WEIMER, W. C. 1995. Environmental design, work, and well being: managing occupational stress through changes in the workplace environment. Aaohn Journal, 43, 458-468.

HOSSEIN-NEZHAD, A., SPIRA, A. \& HOLICK, M. F. 2013. Influence of vitamin D status and vitamin D 3 supplementation on genome wide expression of white blood cells: a randomized double-blind clinical trial. PloS one, 8 , e58725.

JUZENIENE, A. \& MOAN, J. 2012. Beneficial effects of UV radiation other than via vitamin D production. Dermatoendocrinology, 4, 109-117.

KNIGHT, J. A., LESOSKY, M., BARNETT, H., RABOUD, J. M. \& VIETH, R. 2007. Vitamin D and reduced risk of breast cancer: a population-based case-control study. Cancer Epidemiology and Prevention Biomarkers, 16, 422429.

MAITREYA, V. 1979. Integrated design for school buildings. Building and Environment, 14, 119-124.

MANNING, P. 1967. The primary school: an environment for education, Department of Building Science, University of Liverp Ool.

MIRRAHIMI, S., IBRAHIM, N. L. N. \& SURAT, M. Effect of daylighting on student health and performance. Proceedings of the 15th International Conference on Mathematical and Computational Methods in Science and Engineering, Kuala Lumpur, Malaysia, 2013. 2-4.

NEER, R. M. 1975. The evolutionary significance of vitamin D, skin pigment, and ultraviolet light. American Journal of Physical Anthropology, 43, 409-416.

RESEARCH, A. R. I. F. S. B. 1972. School Building Design, Asia, Asian Regional Institute for School Building Research.

SALARES, V. \& RUSSELL, P. 1996. Low-E Windows: Lighting Considerations. A Sustainable Energy Future: How do we get there from here.

TAYLOR, S. L., KAUR, M., LOSICCO, K., WILLARD, J., CAMACHO, F., O'ROURKE, K. S. \& FELDMAN, S. R. 2009. Pilot study of the effect of ultraviolet light on pain and mood in fibromyalgia syndrome. The Journal of Alternative and Complementary Medicine, 15, 15-23.

WILSON, L. M. 1972. Intensive care delirium: the effect of outside deprivation in a windowless unit. Archives of Internal Medicine, 130, 225-226.

WURTMAN, R. J. 1975. The effects of light on the human body. Scientific American, 233, 68-79.

YARHAM, R. 1994. Code for Interior Lighting Chartered Institution of Building Services Engineers (CIBSE). London. 